\title{
Exploring Roles and Relationships in the Production of the Built Environment
}

\section{accepted for publication in the Autumn 2009 issue of the}

\section{Centre for Education in the Built Environment (CEBE) Transactions}

\section{Michael Edwards}

Senior Lecturer, Bartlett School, UCL m.edwards@ucl.ac.uk

\section{Ben Campkin}

Lecturer, Bartlett School, UCL b.campkin@ucl.ac.uk

\section{Sonia Arbaci}

Lecturer, Bartlett School, UCL s.arbaci@ucl.ac.uk

\footnotetext{
Abstract

This is a case study of a compact module aiming to develop understanding of the built environment as a socially-produced set of objects, spatial arrangements and relationships. It invites students in their first university year to explore and question the interplay of professions, industries, economic processes and political structures, doing so partly through content analysis of professional discourse and partly through collaborative detective work with students and teachers from a variety of streams in the built environment faculty. It is a small course, just one eighth of the work done in the first year, and concludes with a short field trip where the methods developed in London are applied to help understand a foreign city quickly from a great variety of perspectives. The course is partly a response to the many criticisms which have been levelled at the rigidity of professional boundaries in the UK and elsewhere and commands warm support from visiting examiners and professionals and from many of its participants.
} 
Keywords:

Discipline; Disciplinary; inter-; multi-; profession; division of labour; discourse; role; agents; functions; architecture, planning, urbanism; construction; project management 


\section{Introduction}

Given the number of agencies and the complexity of institutional and professional relationships in the production, management and regulation of the built environment, many students entering built environment professions leave university without a sufficient understanding of these diverse actors, and the formal and informal interactions and social dynamics between them. Furthermore, stereotypes form during the educational process as students construct their own professional identity, in part learnt from their teachers and peers, and naturalised by the academic and professional institutions that form the context of their education - a process of enculturation termed 'professional socialisation' by social scientists (Cuff, 1991: 118). These stereotypes may lead ultimately to inter-professional tensions and hostilities. Innovations in practice often involve challenges to established roles or demonstrate joined-up thinking which breaches institutional structures, for all of which graduates may be ill-prepared.

In this case study we outline an interdisciplinary module, Production of the Built Environment, taught to first-year undergraduate students in the Bartlett (Faculty of the Built Environment), UCL. The course is currently taught to BSc Architecture, Urban Studies, Urban Planning, Design and Management, and Project Management for Construction students, as well as affiliate students from other disciplines such as History of Art and Anthropology. We consider Production of the Built Environment to be both multi-disciplinary and interdisciplinary it encourages the transformation of each discipline through engagement with others. (On the distinctions between multi- and interdisciplinary working see Rendell (2004).) Our aims in this short paper are two-fold: firstly, to contextualise the course and its preoccupations in order to stimulate debate around its themes. Secondly, to describe the course and its format, focusing in particular on the project-work elements. Our hope in doing this is to provide a resource which might be useful to other built environment faculties running, or thinking of running, interdisciplinary courses. We consider that it is particularly important to share examples of good practice in this area of teaching, given the practical challenges, institutional and professional barriers, and other resistance to such initiatives. There is no particular reason why such work should be limited to the UK and we know of attempts to do parallel teaching elsewhere in Europe. Indeed the presence of teaching staff trained in non-British regimes, and of exchange students in Socrates/Erasmus, has been a continuing influence on the course and there may be scope for international cooperation in the further development of these practices. 


\section{The context and continuing need for the course}

The course addresses three main issues: (i) the widespread problem of dysfunctional relationships and 'blame' culture between professions, (ii) a rather specific problem of the architect as 'star', and (iii) the long-term and broad understanding of the division of labour in society as a whole - or at least that part of society producing the built environment.

\section{Understanding and challenging stereotypes and the 'vices' of professionalism}

The Production of the Built Environment course is didactic in enabling students to gain an initial understanding of how today's professional roles in the urban development process have emerged, how they vary, why they change and what their future might be. More importantly, however, it challenges students to think critically about professional identity and relationships right at the start of their university education, rather than simply and passively adopting a predetermined mindset, or consciously modelling themselves on others around them. In this way the course aims to put the 'rites of separation' (Cuff, 1991: 153) of entry-level students on built environment courses in the spotlight, examining the processes of enculturation which individual students experience as they become associated with a profession, and therefore distinct from the 'laity'. Critical reflection on this process is considered to be equally important for all professional streams, for individuals who will have to find themselves niches in a fast-changing constellation of organisations and activities. A more heightened awareness of professional socialisation can be instrumental in reducing the negative impacts of exclusivism and conservatism which Frank Duffy, as President of the Royal Institute of British Architects (RIBA) in the mid-1990s, argued to be the 'vices' inherent to the structures of professionalism (Duffy in Pearce and Toy, 1995: 120).

That Duffy publicly criticised the vices of professionalism at that time indicates something of the wider cultural context in which the Production of the Built Environment course was conceived. The 1980s and 1990s saw increasing scrutiny of the role of professionals and professional bodies and their utility to wider society, prompted by a common perception that they were self-serving and backward-looking. The course grew in part from the international research collaboration of the Bartlett International Summer Schools (BISS, 1979-96).

The course was set up in the mid-1990s, encouraged by criticism from external examiners that the Faculty's advertised claims to interdisciplinarity in the teaching of built environment students were empty rhetoric - or at least not evidenced in taught courses and student learning. This criticism came at a time of broader condemnation of the construction industry's organisational structures, working practices and 
relationships, and methods of communication, articulated in particular through the Latham (1994) and Egan (1998) reports. In addition, in the specific context of architectural education the Burton Report (1999) reiterated a recurring theme of Latham and Egan calling for institutions involved in the education of architects to pay more attention to a need for cross-disciplinary working (summarised in Pearce and Toy, 1995: 122-123). The 1990s were equally a turning point for urban planning in Britain. After a decade in which deregulation and the private individualism of the Thatcher period had weakened and discredited planning, planners and planning students often felt the contempt of more 'creative' or entrepreneurial professions. By the early 1990s, however, the instabilities of de-regulation had taken a heavy toll in developer bankruptcies and aborted developments and even quite conservative forces in British society were calling for a renewed form of planning to manage development risks, set parameters for urban design and contain environmental damage. The 1990s were thus the start of a creative and dynamic period for all our professions. It has not, however, been an uncontroversial period and the course has been able to draw on critical debates about planning versus markets, commodification of the environment and so on.

Just as in architecture, planning and construction professions transmit disdain and even contempt for others in the formation of new cohorts. It is common in the UK for students in planning to exhibit a mixture of envy and contempt for architects who are often seen as creative but 'airyfairy' people, blind to the practicalities of life and often unaware of the social, economic and environmental stresses in wider society. These attitudes may go back to the Schuster report (1950) which initiated the shift towards town planners as social scientists, defining themselves increasingly as not architects, not designers. In recent decades there has been tension between that social-scientific concept of the planner and a design-based alternative which has drawn strength from the southern European tradition of Urbansimo / Urbanistica (Piccinato, 1987) and from the north American 'New Urbanism' movement (Talen, 1999). Although Hebbert (2006) argues that the battle is over and urbanism is victorious, this teaching programme treats it as an open question because the young planner today has to construct his or her identity within this cultural controversy and among the internal debates of the social sciences.

If planners have often been blamed for ignorance about design, architects are often viewed as reluctant to accept responsibility for the social and environmental imperatives articulated through planning policies and to engage in the communicative process among diverse interests which planners try to facilitate. Similarly in the training of construction managers it is still common to find that other professions are viewed as essentially a source of fancy ideas, delays and impediments to the brisk and profitable execution of projects. This can be a world of stereotypes 
and blame. One aim of this teaching programme is at least to enable people to see these stereotypes as what they are, to laugh about them and to feel strong enough to challenge them.

These debates of the 1990s led to some innovations in forms of contracting but calls for further changes in practices and in education have continued. Mr Prescott's Urban Task Force report (UTF 1999) extended the debate to 'urban design', planning and urban policy spheres, sparking innovations at the turn of the century at the interface of architecture and planning. Gerard Wood argued (2000) that since the criticism of the industry's lack of collaboration between professionals in the late 1980s there had been a gathering momentum in the form of further research and reports and conferences which have echoed earlier sentiments. In this widened form, the debate was more recently crystallised in a useful set of seminar papers edited by Foxell (2003).

\section{Individualism versus interdependence}

Anticipating the issues raised by these reports, the course aimed to challenge the familiar educational models of the built environment professions which were seen to have prevented cross-disciplinary cooperation. It is perhaps especially important that, in the teaching of architecture, the predominant pedagogical system had an emphasis on producing star students - and ultimately star architects - through nurturing individual creativity in the design studio at the expense of collaborative or interdisciplinary work. This model has been remarkably resilient despite both internal and external criticism for encouraging what sociologist Herbert Gans dubbed the 'Fountainhead syndrome' (Gans in Risebero, 1992: 93), referring to Ayn Rand's Howard Roarke character in The Fountainhead (1946).i Dana Cuff terms this the 'myth of the autonomous architect-hero' (Cuff, 1991: 1). In her critique of the culture of contemporary architectural practice in the USA, Cuff describes her own experience of being innocently hood-winked by this myth on arrival to study architecture in a studio-based educational context which valued the 'primacy of the individual' above all else. The origins of this approach lay in the studio apprenticeship model in which young artists or architects would learn by doing in the studios of Michelangelo or later Great Men. The model was absorbed into the academy when university education took over from the apprenticeship/articles approach in the nineteenth century. And it is not confined to the educational stage: London still has droves of young architects who have come to spend a few years in the studio of Foster or Rogers, Hadid or Chipperfield. As Lance Hosey has written, again in the context of North American architectural education: 'The mystique of the lone visionary artist is compelling, but it also fuels the egotism commonly associated with designers. Howard Roark, famously is both the hero and villain of architecture' (Hosey, 2008). 
In the UK, entrants to professional degree courses are also influenced by their pre-university experience of studying A-levels which have also been criticised for over-emphasising the merits of individual achievement (Torrington, 2000: 85).

In contrast, this module attempts to de-mystify the production of the built environment at the earliest possible stage by highlighting its constitution as a social, rather than individual, construction product, created by many hands and in the context of larger socioeconomic and political forces.

In an autobiographical article which makes reference to her own experience of architectural education, Jane Rendell reinforces Cuff's observations (Cuff, 1991: 56) on architects' denial of other roles in the design and production of buildings:

I was told the amazing story of architecture, of how architects did architecture all on their own. As if by magic, they imagined architecture, and then, with minimal fuss, and certainly no mess, they made it [...] I was told that architects were important people, very important people, the most important people in the building trade. For architects, the building trade can be used metaphorically - to refer to the world (Rendell, 1998: 230).

A suspicion of the authority of the individual 'creative genius' or cultural producer, and the 'death of the author,' form part of a wider cultural shift from modernism to postmodernism (Harvey, 1989: 51; Barthes, 1977). And yet the 'fountainhead syndrome' has been notably persistent in architectural education, despite publications which have convincingly challenged the 'natural' authority of the architect, and those that have criticised the profession's conception of the user of architecture as a 'stable, centralised and passive subject' (Hill, 1998: 3).

\section{The division of labour}

Underpinning all of these debates lies a fundamental concept which helps to inform pedagogy in this field: the division of labour, i.e. the breaking-up of all the world's work into specialised fragments - trades and professions, contractors and subcontractors, designers and makers, borrowers and lenders, producers and consumers. Integral with the endless division and fragmentation of labour has been the increasing importance of exchange to coordinate and assemble society's complex commodities (the city, the building, the computer) as great cooperative products. The concept has run through the work of Plato, Adam Smith, Henry Ford and Henry Winslow Taylor and is alive today in areas as diverse as gender studies and management consultancy. One of its powerful features is that it stresses the inter-dependence between distinct 
sectors of the economy and led Janssen (1983), for example, to estimate that about a quarter of all the activity in a modern economy may be linked to the production, management, marketing and maintenance of the built environment (Figure 1). This is a fact which many students find stirring, others daunting. Our aim here is to encourage students to grasp the context in which they work- their roles and relationships in a wider urban and socio-political context - and the opportunities it presents.

\section{Figure 1: Employment in the production and use of the built environment.}

Based on Jörn Janssen (1983). The estimate related to western Germany in the 1980s and the author concluded that the total area of the chart (where areas are proportional to numbers of workers) represented about a quarter of all national employment. This research formed part of the work of the Bartlett International Summer Schools on the Production of the Built Environment (BISS) 1979-96 which were in some ways a precursor of the present project. 
Production of plant and

machinery for

building

Produclion of maleriak

Construction industry

repair + maintenance

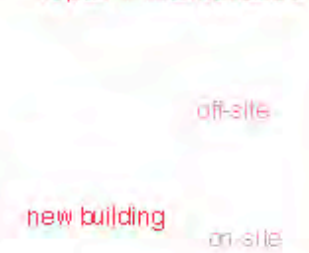

Design, planning, law, finance, surveying, marketing, credit.$/$ tinance

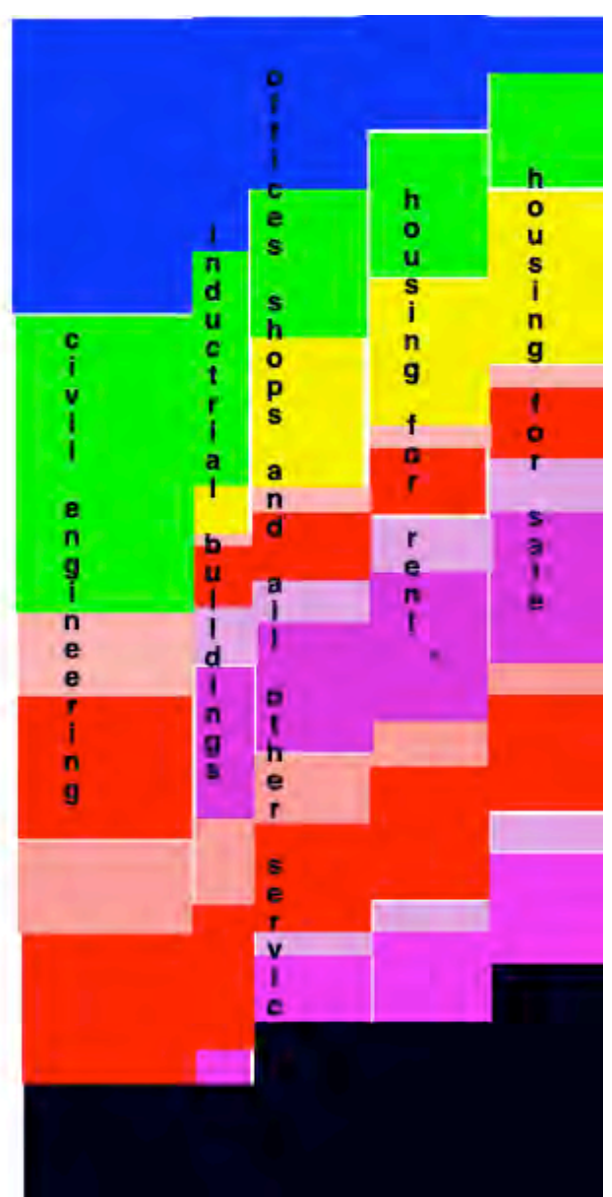

The paper so far has summarised the principal intellectual and professional concerns which, in various ways, underlie this course on the Production of the Built Environment. It will be evident that we are concerned with exploring and questioning relationships of all kinds in the process - from relations between professionals to forms of contract, from international trade flows to the tenancies of London offices. All of 
these can be explored partly through observation of the physical world, but everything we do has to be expressed and discussed using language, so it is with language that course begins. And the rest of this paper sets out the structure and content of the course.

\section{The structure and content of the course}

The course is taught partly by lectures to approximately 180 students, supported by seminars in groups of around 20-25, with individual coursework and interdisciplinary group project work, and a week-long overseas field trip (to Istanbul, Palermo, Bilbao and Athens in recent sessions). See figure 2. It is delivered by a multi-disciplinary team of tutors - architects, planners, economists, architectural historians, project managers, urban sociologists - drawn from the different Schools within the Bartlett - School of Planning, School of Architecture, School of Project Management. Some tutors are full-time academics while others are practitioners. In addition to the core team, one-off lectures are given by visiting practitioners.

\section{Lectures}

Lectures occupy only about 8 hours of the 100 or more which each student spends on the course, but they do play an important role in proposing analytical frameworks and concepts and in unifying an otherwise group-based experience. They focus on specific examples of relationships and then question how and why those relationships formed and whether or not they were successful, from the distinct perspectives of the different parties (built environment professionals, but also others affected such as building users or investors). This requires students to think both at micro and macro scales and to reflect, even before they might be comfortable within it, on the social relations of the educational environment and its relationship to a 'real' world. Furthermore, the course provides the opportunity to question that 'real' world itself. As Bill Risebero argued in the early 1990s one might usefully question:

[...] how real anything is under capitalism, the system in which real relationships between people are turned daily into unreal ones, defined by money and objects. On this level, even the eminently practical world of the building industry is no more nor less real than the schools are, no more nor less alienated, exploiting and objectifying as it does the potential creativity of all those involved in it.

(Risebero, 1992: 96-97) 
The lecture series begins with a talk explaining the concept of the division of labour, and professional acculturation, laying stress on some positive features of professional identities. Building on this introduction, three lectures introduce the three main professions that the students are affiliated with, giving a positive slant on the creative potentials of each. Case study lectures then focus on projects with exceptional, innovative, working relationships, demonstrating to students that their own professional identities, and those of other built environment professions and social agents are in flux and open to negotiation and new possibilities - a fact which may often be concealed during the educational process. Recent lectures have included, for example, Julia Barfield speaking on the London Eye where the architect was the initiator, managed to execute the project without a client and secured approvals despite the scheme being totally at odds with all the formal plans and policies of governments and quangos. A few metres away is the Coin Street Community Builders development, the subject of a lecture by Christine Czechowski. Here - thanks to securing ownership of the land in a protracted struggle - local community groups have managed over 20 years to create a cooperatively-owned neighbourhood, serving locals, Londoners and tourists, exploiting crafty crosssubsidies and investing the money they save (by not paying land rent) in higher quality architecture, building and management. A representative from the office of an ex-Bartlett architectural practice provides another of the core lectures, a talk structured around RIBA work stages A-D by Susan Le Good of AHMM, which draws on case studies from the practice's work to illustrate imaginative collaborative working relationships with others, such as artists, furniture designers, academics and building contractors, which challenge the 'fountainhead syndrome' (on the work of AHMM see Borden, 2003). A severe cultural shock is then administered in a lecture by Dr Andrew Edkins, a distinguished advocate and practitioner of the PFI procurement of prisons. Here the argument essentially is that accurate contractual specification of the objectives of a building (reduced re-conviction, safe incarceration etc) brings social effectiveness into line with maximising shareholder value, the architecture being purely instrumental. 
Figure 2 The student tasks: The main work of the course takes place in three Tasks, the character of which is summarised here. Task 1 occupies the first 2 weeks of the course, Task 2 about 8 weeks and Task 3 occupies just 3 days during an overseas field trip.

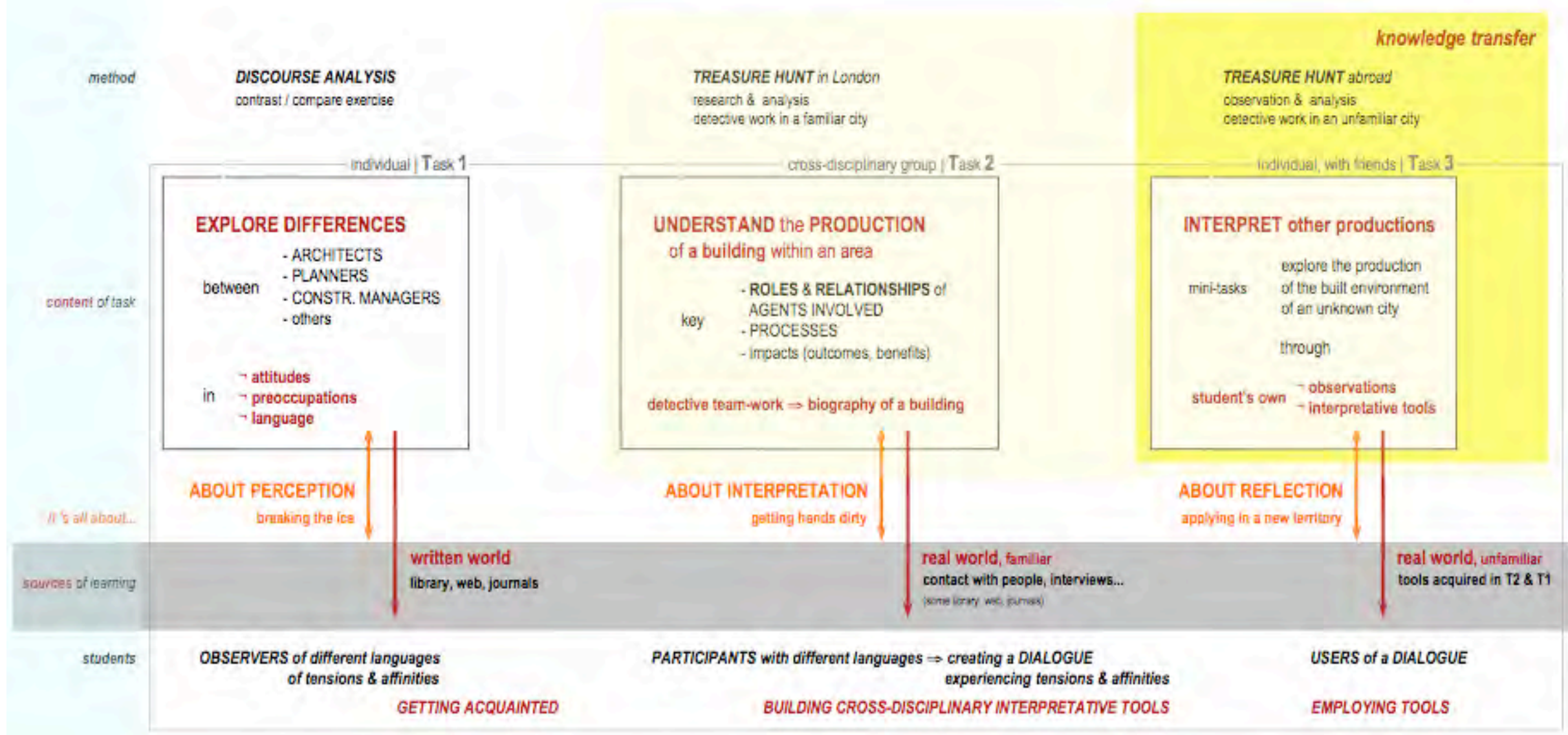




\section{Task 1 (2 weeks)}

Students write a short individual essay of one thousand words contrasting the narratives of a given building, in the magazines of different professions. The task requires students to visit the library and undertake rudimentary research, finding articles about the building in a range of different professional journals and magazines (three references for each building are provided to give students a start). Each article must be analysed in terms of the language and preoccupations of the professional group it addresses, with students drawing conclusions about the concerns, modes of discourse and methods of representation of the distinct groups. This simple discourse analysis is (intentionally) unsettling, and yet extremely productive, for students who are often not yet familiar with the ways of seeing and discussing the built environment adopted by the professional groups to which they have provisionally assigned themselves.

\section{Task 2 (8 weeks)}

Students then work in multi-disciplinary teams of 4 or 5 students (architects, planners, project managers from within the Faculty, as well as others - anthropologists, art historians, etc. - taking the course as an elective from elsewhere in the university) to analyse the roles and relationships evident in the production of a London case study development and its consequences for the city and citizens. Over an eightweek period they plan and undertake a research project with the aim of reaching a sophisticated understanding of why the development took place and the parts played by all the actors involved, from government officials to bricklayers, from architects to final users, from pension funds to letting agents. Rather than examining only 'iconic' buildings, students also research the buildings and urban spaces and processes which form the 'background' or normal fabric, of the city. The course adopts former UCL Professor Richard Llewellyn Davies's definition of the objects of our work as everything from 'city plan down to the door knob' (Llewellyn Davies, 1961), and beyond that, of the building stock as inhabited and experienced, a product of people and of failures and successes.

Participants are required to undertake original and detailed research work, and in doing so they learn useful observation and research skills and, supported by their tutors, come into first-hand contact with a wide range of built environment professionals, building occupiers and others such as civic activists or local authority archivists. They quickly find that the library is not enough and are driven to creative detective work and interviews with participants and users. Successful completion of the project requires each team to formulate a research plan and methods fitting to the particular building they have been given. Groups working on a late 1990s commercial office development will find 
themselves faced with quite different challenges of finding and interpreting information compared to a group who have been allocated, for example, the recent renovation of an $18^{\text {th }}$-century church.

Each tutor sees their group of about 25 students (divided into about 5 working teams) for one afternoon each week. The tutor will have chosen a particular area in which are located all of the developments the teams are to examine, with a mix of different functions, scales and historical periods. Recent districts have included the Elephant and Castle, Bermondsey, Soho, Hoxton, Shoreditch and Docklands. As the groups feed back on the progress of their research they learn from each other about other buildings in the area, about the broader planning and context of the location, and about the impacts of the building on the locality and its communities. Common themes may emerge such as a shared political/planning policy environment or an enduring social class composition in the locality, rapid gentrification, or sudden entry of new kinds of investors. At first, students visit their building and area with their tutor, before going on to conduct independent research.

The group work inevitably presents challenges - tensions in working relationships and trust, and the practicalities of realising the project within a limited timeframe - which reflect a 'real' project. However, though initially daunted, the majority of students respond imaginatively, enthusiastically adopting the role of 'detective', piecing together a biography of their building. Many of the buildings have not been 'published' and so a creative approach to research is required - drawing, for example, on empirical observation, interviews, and archival searches.

Students can become passionate about their own discoveries and the tutor is often mediating and linking, or helping people find appropriate language to use among themselves or in presentations. We are not suggesting that the course is entirely unique in its approach to multidisciplinary group work. For example, Judith Torrington has described a first year project at the University of Sheffield with some similarities. The objective of the project, which involved role-play, 'was to foster the development of group working and communication skills through learning tasks involving real clients, users and people with expertise in disciplines related to architectural design' (Torrington, 2000: 84). Student feedback on the group work echoed feedback on the group projects attached to the Production of the Built Environment course in highlighting the difficulties of such work (often a deterrent to tutors as much as to students).

Groups present their findings at various stages to their tutors, peers and visiting practitioners, leading to stimulating discussions regarding the processes and inter-professional relationships which influence the production, successes and failures of specific developments. They do this finally in a 10-minute presentation (power point, video or other media) and also in an illustrated project report. Figures 3 onwards here give some impressions of what students have chosen to present as the more analytical parts of their work in task 2. 


\section{Task 3 (3 days)}

Students then attend a field trip and undertake a similar project in a different European city, requiring them to apply to another city the techniques and concepts they have developed in London - a process of comparison which can often generate insights about the distinctive qualities of the UK situation. The format of both projects could be easily transposed to the context of any other city - indeed, it is a central tenet of the course philosophy that the analytical approach, focusing on processes and relationships, can be usefully and revealingly applied to the study of any built environment. For example, a coach load of us arrived in a shanty settlement (a mature gecekondu) in the periphery of Istanbul, got out and started exploring. After a short time half the students (more males than females) had engaged the local youth in football - Turkey $v$ the Rest of the World - while the other half, more women than men, had started a comparative analysis of informal settlements around the world. There turned out to be student experts from Djakarta, Rio, Medellin and various towns in China in our group so a very informed and useful discussion took place, with the British students keeping up as best they could.

This third task, although very short, provides the essential opportunity for students to realise that they have learned a lot, that they can deduce something about the structure of a society, its politics, planning and its construction industry from looking at buildings and localities, that there are ways of estimating the wealth or poverty of a neighbourhood's residents from glimpsed interiors, parked cars and laundry. The timing and character of rush-hour passengers can offer clues to economic life and the intensity of work. The very fact that (for most students) the language spoken in the chosen city is an unknown one forces more reliance on visual clues instead of documents: block sizes as hints about land tenure; disjunctures between adjoining buildings as clues to altered plans (or sometimes to corruption). Some phenomena, though, defy interpretation. None of us could figure out why new buildings in Palermo had such massive basements - and the Architecture School was built in the bottom of a deep hole. We had to ask a local professor who explained that this was our first tangible sign of Mafia activity: if you want a development to go well here, he explained, it is wise to have a very large earth-moving contract.

\section{Concluding remarks}

The images at the end of this case study paper (Figures $3-8$ ) give some idea of the analytical frameworks used by students in some recent group submissions and the web link leads to an archive with PDF versions of some of their presentations and reports.

http://www.bartlett.ucl.ac.uk/planning/programmes/modules/1019 
The student body typically comprises about half UK students and half people from across the world. The latter bring valuable perspectives with them about how the built environment is formed and used, formal professional institutions, how professionals work, and so on. Student diversity (which is an increasingly common situation in UK HEIs) strengthens the learning experience of all participants (CEBE, 2006). Open discussion of cultural differences in professional and socio-political contexts helps to avoid the overseas students feeling marginalised, indeed the Istanbul episode reported above was an occasion when the Brits felt left out. Through their project work students unfamiliar with London also have the opportunity to get to know an area and a specific building in detail.

The Latham and Egan reports and the Urban Task Force criticised the built environment professions' poor communication skills, and lack of inter-professional dialogue. In an industry with increasingly complex communication challenges (Yanik and Hewett, 2000: 60) there is also a sense that students are somehow expected to develop the necessary skills without support, or in a stressful or hostile context. The course tries to lay a foundation for doing this explicitly and for pleasure.

This experience acts to give students a better-informed basis than they usually have at school for directing their careers and each year it is common for a few students to decide to switch, either to a different professional or academic route within the faculty or occasionally to another field elsewhere in the College.

The module makes explicit, and provides a context for understanding and challenging, professional 'status anxiety' (de Botton, 2004). The course positively encourages students to think about why different professional groups and individuals have adopted particular attitudes, stereotypes, codes, territories, effective or ineffective, reciprocal or antagonistic relationships; in response to anxieties and insecurities about their own status, role or position in a hierarchy, or that of their professional group. Rather than simply accepting the Egan view that the different actors and agencies involved in the production of the built environment should try to get along and work together more effectively, the course attempts a more critical understanding of the social dynamics of the development process, and the external perception of the industry and professional groups within it, not just professions and firms, but also investors, citizens, neighbours, users, politics and planning.

We consider this an innovative and thoroughly enjoyable teaching/learning project. It changes a bit every year and will undoubted change further in the future. It is periodically criticised by colleagues in professional streams who would prefer to have 'their' students for $100 \%$ of the time, and it has not yet been possible to carry this kind of approach into later years of study. Students do, however, carry their experience of this module through their later studies (and, we hope, their lives) and we know from continuing contact that it is strongly formative for many of 
them. We also notice, in 2008/9, that this course is an arena in which many students discuss the economic crisis, and not just as passive victims: they begin to see themselves as active agents in the world. 


\section{References}

Barthes, R. (1977) The Death of the Author, Image-Music-Text, trans. S. Heath. London, Fontana, p. 142-8.

Borden, I. (2003) Manual: the Architecture and Office of Allford Hall Monaghan Morris. Basle, Birkhäuser.

de Botton, A. (2004) Status Anxiety. London, Hamish Hamilton.

Centre for Education in the Built Environment, Guide to Supporting Student Diversity in UK Schools of Architecture,

http://www.cebe.heacademy.ac.uk/learning/sig/equality arch/index.php 2006

Cuff, D. (1991), Architecture: the Story of Practice. Cambridge, MA, and London, MIT Press.

Duffy, F. Education in Architecture in Martin Pearce and Maggie Toy (eds.) (1995) Educating Architects. London, Academy Editions.

Egan, Sir John (1998) Rethinking construction: the report of the Construction Task Force to the Deputy Prime Minister, John Prescott, on the scope for improving the quality and efficiency of UK construction. London, Department of the Environment, Transport and the Regions.

Foxell, S. (2003) The Professionals' Choice: The Future of the Built Environment Professions. London, Building Futures for CABE and the RIBA.

Harvey, D. (1989) The Condition of Postmodernity. Oxford and Cambridge, MA, Basil Blackwell.

Hebbert, M. (2006) Town Planning versus Urbanismo. Planning Perspectives. 21 (3) 233-251 July.

Hosey, L. (2008), The Fountainhead Syndrome http://www.aia.org/nacq a 050714 out syndrome

Hill, J. (ed.) (1998) Occupying Architecture: Between the Architect and the User. London and New York, Routledge.

Hill, J. (1998) The Illegal Architect. Occupying Architecture: Between the Architect and the User. London and New York, Routledge.

Janssen, J. (1983). "The Formal and Real Subsumption of Labour to Capital in the Building Process." Proceedings of the Bartlett

International Summer School on the Production of the Built Environment (BISS). 4: 2/2-10. 
Latham, M. (1994) Constructing the team: joint review of procurement and contractual arrangements in the United Kingdom construction industry. London, HMSO.

Llewellyn Davies, R. (1961) The education of an architect. Inaugural Lecture 1960. London, University College London.

Piccinato Giorgio (1987) Las teories del urbanismo; un intento de analisis. Urbana 7, 9-14.

Rand, A. (1946) The Fountainhead. Indianapolis and New York, Bobbs-Merrill Co.

Rendell, J. (1998) Doing it, (un)doing it, (over)doing it yourself: rhetorics of architectural abuse in Jonathan Hill (ed.) (1998) Occupying Architecture: Between the Architect and the User, London and New York, Routledge, p. 229-246.

Rendell, J. (2004) Architectural Research and Disciplinarity. Architectural Research Quarterly. 8, 4, p. 141-7.

Risebero, B. (1992), Fantastic Form: Architecture and Planning Today. London, The Herbert Press.

Schuster GB Ministry of Town and Country Planning (1950). Report of the committee on the qualifications of planners (The Schuster Report). London, HMSO Cmnd 8059.

Talen, E. (1999). Sense of community and neighbourhood form: An assessment of the social doctrine of new urbanism. Urban Studies 36(8): $1361-1379$.

Torrington, J. (2000), The development of group-working skills and role play in the first-year architecture course in David Nicol and Simon Pilling (eds.) (2000) Changing Architectural Education: Towards a New Professionalism. London and New York, E \& FN Spon.

UTF (1999) Urban Task Force Towards an Urban Renaissance. London, Routledge.

Wood, G. (2000) Interdisciplinary working in built environment education in David Nicol and Simon Pilling (eds.) (2000) Changing Architectural Education: Towards a New Professionalism, London and New York, E \& FN Spon.

Yanik, J. and B. L. Hewett (September 2000), An argument for argument in architectural education. Journal of Architectural Education 54/1. 
Paper submitted for CEBE Transactions

Figure 3 (a and b) Cargo | by Daniel Hall, Anah Hosein, Afra van'T Land and Madalena Ferreira Neto

The students presented two complementary diagrams. One looks at roles/relationships of Cargo development across four stages. The second set the story of Cargo within a wider context, by looking at the impact of Cargo in Shoreditch (a gentrification discourse) and the evolution of Cantaloupe group. When the owners of Cantaloupe restaurant decided to open Cargo, they formed the Cantaloupe Group (http://www.cantaloupegroup.co.uk/), and after the success of Cargo they opened two more bar/restaurants/music venues: 'the market place' close to Oxford Circus and 'the big chill' in Pentonville Road. Subsequently, they have opened 'casual' a record place.

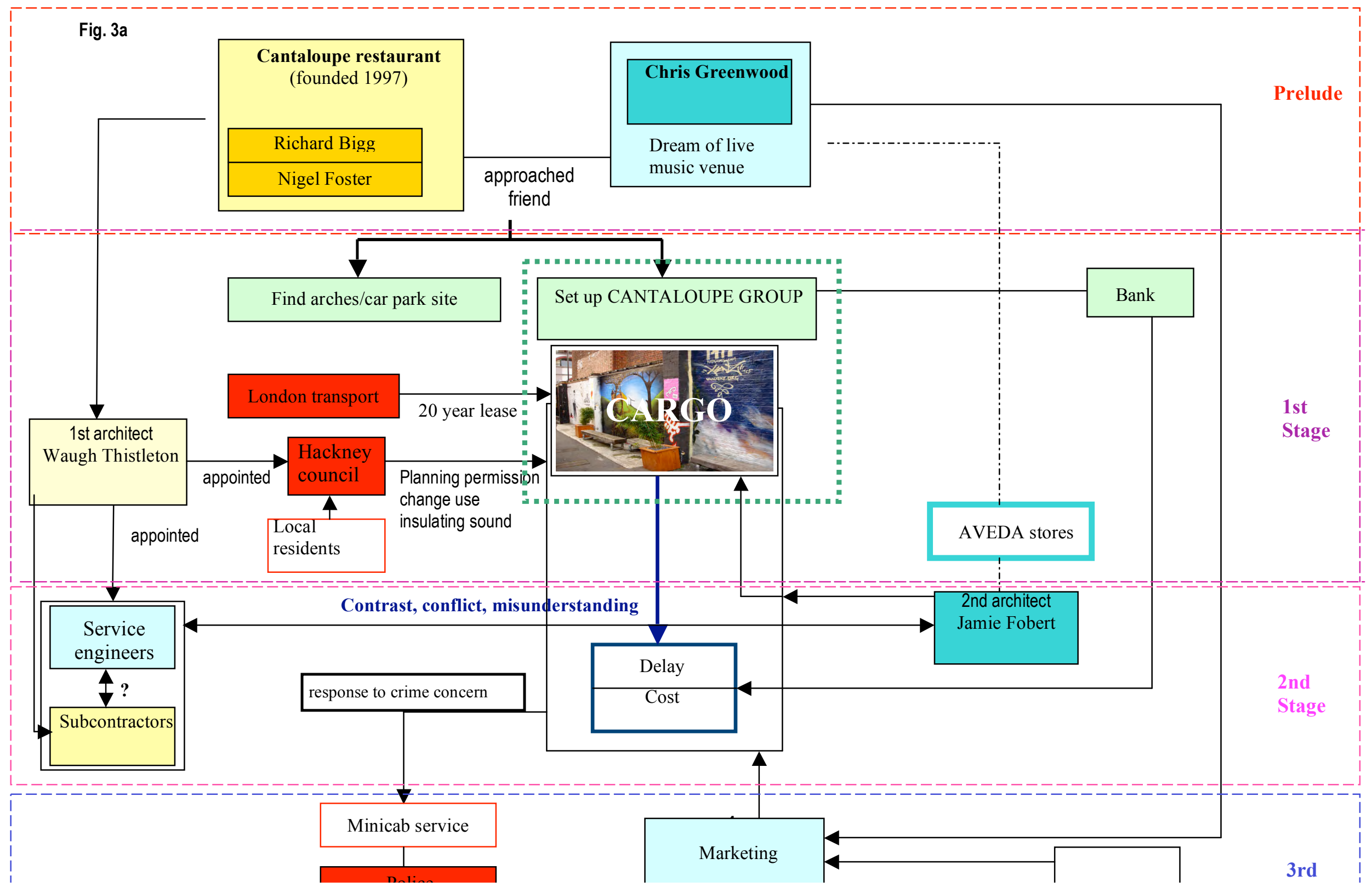


Double click here to type title of paper

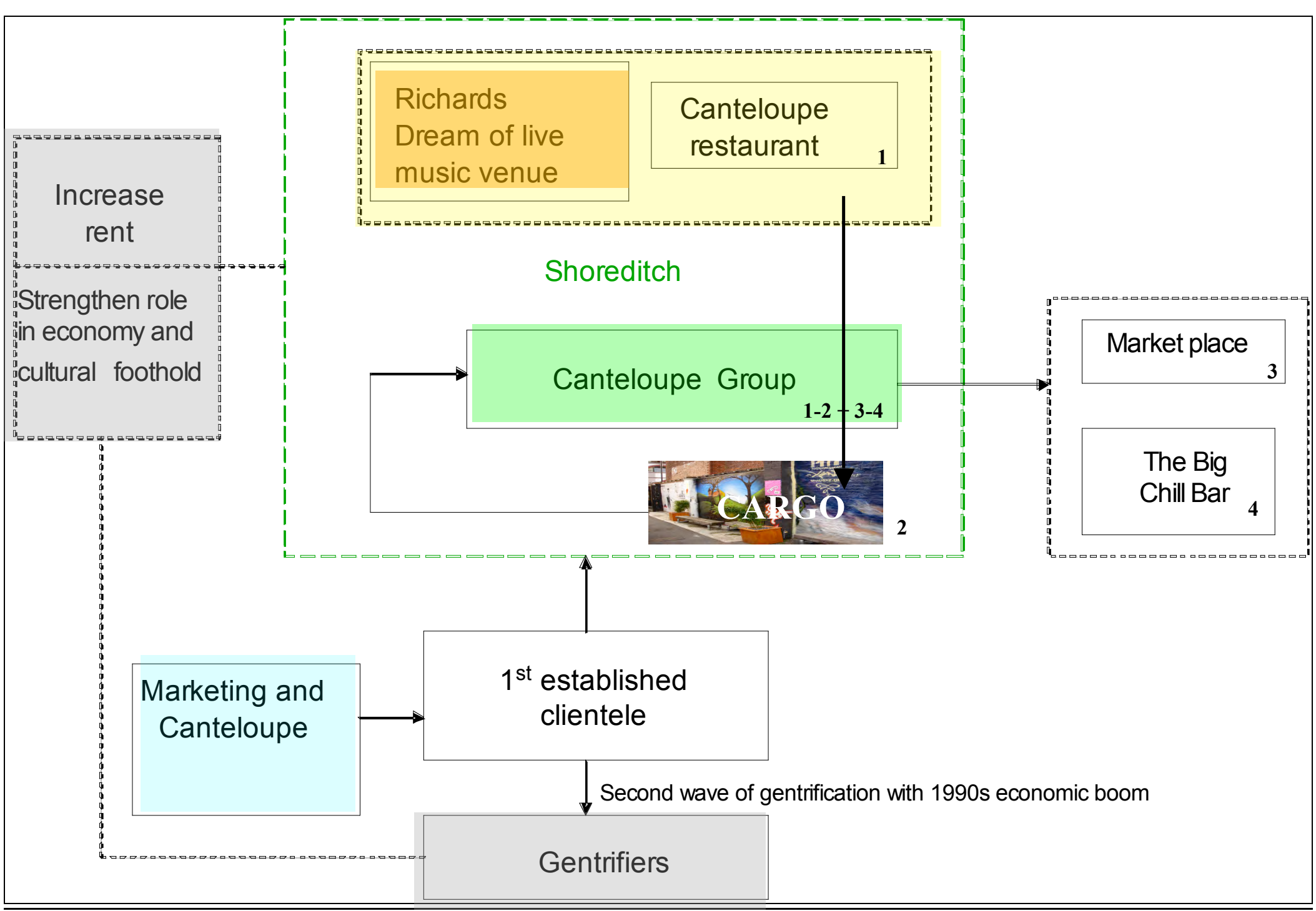

Fig.3b 


\section{Double click here to type title of paper}

Figure 4 Old Spitalfields Market | by Jason Claxton, Jan Balbaligo, Caroline Huett and Laura Herriotts

The students developed a timeline to encapsulate their understanding of the processes involving the redevelopment of Spitalfileds market into office blocks, designed by Foster. Particular attention has been paid on changes in ownership, finance, production and use, as well as the dispute between City of London Corporation and Spitalfields residents about the redevelopment of the western end of the Market

\begin{tabular}{|c|c|c|c|c|c|c|}
\hline & Previously & 1987 & $1989-1996$ & $1996-1997$ & $1998-2001$ & $2002-2005$ \\
\hline 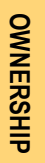 & London Borough of Tower Hamlets & $\begin{array}{l}\text { Spitalfields Development Group } \\
\text { purchases a } 150 \text { year lease for the site } \\
\text { from Tower Hamlets }\end{array}$ & SDG & SDG & $\begin{array}{c}\text { SDG is bought by } \\
\text { Corporation of London and Hammerson } \\
\text { PLC }\end{array}$ & $\begin{array}{c}\text { SDG } \\
\text { (now owned by Corporation of London } \\
\text { and Hammerson PLC) }\end{array}$ \\
\hline 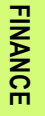 & Tower Hamlets & $\begin{array}{l}\text { Corporation of London } \\
\text { (who partly owned SDG) }\end{array}$ & As before & As before & Hammerson PLC & As before \\
\hline $\begin{array}{l}\text { 끙 } \\
\text { 은 } \\
\text { 금 }\end{array}$ & None & None & $\begin{array}{l}\text { Fruit and vegetable market moved to a } \\
\text { new site in Leyton, subsidised market and } \\
\text { retail facilities set up } \\
\text { Planning permission granted in } 1993 \text { for } \\
\text { first phases of scheme }\end{array}$ & $\begin{array}{c}\text { Construction of first phase of proposed } \\
\text { redevelopment begins } \\
\text { planning permission for final phase } \\
\text { granted }\end{array}$ & Major office work and building continues & $\begin{array}{l}\text { New pavilions and Foster office blocks } \\
\text { completed. } \\
\text { Planning permission for Bishops Square } \\
\text { granted and construction begins }\end{array}$ \\
\hline 恖 & $\begin{array}{l}\text { Wholesale fruit and vegetable market } \\
\text { (located here since late 1600s) }\end{array}$ & Fruit and veg market & $\begin{array}{l}\text { Current stall market moved into the } \\
\text { Horner Buildings }\end{array}$ & Stall market and construction site & $\begin{array}{l}\text { Stall market remains but redevelopment } \\
\text { continues around it }\end{array}$ & $\begin{array}{c}\text { Boutiques and coffee shops occupy new } \\
\text { pavilions, reduced number of stalls remain } \\
\text { in Horner buildings }\end{array}$ \\
\hline $\begin{array}{l}\text { 뀨 } \\
\text { 㽞 } \\
\text { 眊 }\end{array}$ & None & None & $\begin{array}{c}\text { None } \\
\text { residents happy with new stall market }\end{array}$ & $\begin{array}{l}\text { SMUT formed in resistance to plans for a } \\
\text { Norman Foster office block }\end{array}$ & $\begin{array}{l}\text { SMUT takes legal action } \\
\text { in an attempt to prevent the market being } \\
\text { replaced by new shops and offices. } \\
\text { As a result, several architects have to } \\
\text { resubmit planning applications }\end{array}$ & $\begin{array}{l}\text { No attention paid to SMUT's protests, } \\
\text { redevelopment gone ahead without } \\
\text { residents input }\end{array}$ \\
\hline
\end{tabular}


Figure 5: Centre Point - getting to grips with plot ratio and bargaining | by Matt Burgess, Charlotte Bamber and Tom Dichmont

\begin{tabular}{|l|l|}
\hline Plot Ratio & $\begin{array}{l}\text { Normally, floor area of build restricted in relation to } \\
\text { plot area at 5:1 ratio. i.e. } 5 \text { times as much built } \\
\text { floor area as size of plot }\end{array}$ \\
\hline
\end{tabular}


Figure 6: More London | by Joanne Preston, Ahmed Patel, Aaron Ho, Jenny Yung

An entire seminar group worked on aspects of this development, in which City Hall is one leased building in a very extensive (and otherwise speculative) development. This group studied the many off-site projects which were provided as parts of the Section 106 agreement between the developers and Southwark Council.

\section{MORE LONDON SECTION 106 PROJECTS}

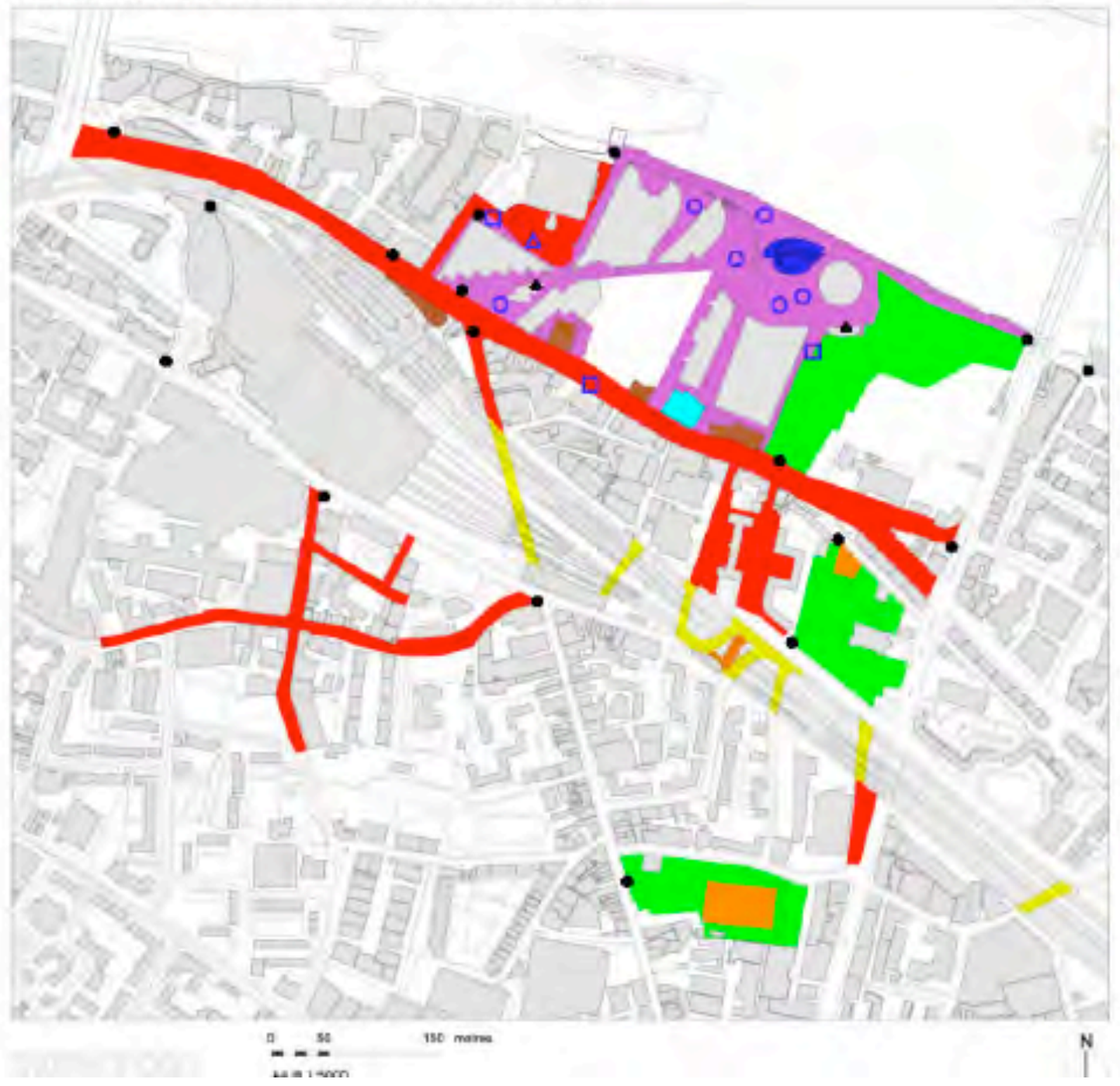

\section{Legend}

Public Roam Project

Sporta/ Pray Projects

Railway Arch Proects

- Open Space Projocts

- Public Erent and Perfornance Speose

- Mare London Open Space

Unicom Thaarme

- Histone \& Horitage Building Refurbishments

ㅁ. Cycle Parking Stands

$\triangle$ Coach Drop-ott

- Antwork

- Public Toinets

- Waytinding 
This diagram shows the Significant Dates in the Production of Plot 1 of More London. Students gathered the information from company websites, newspaper articles and journals and confirmed the story whilst interviewing Grant Brooker.

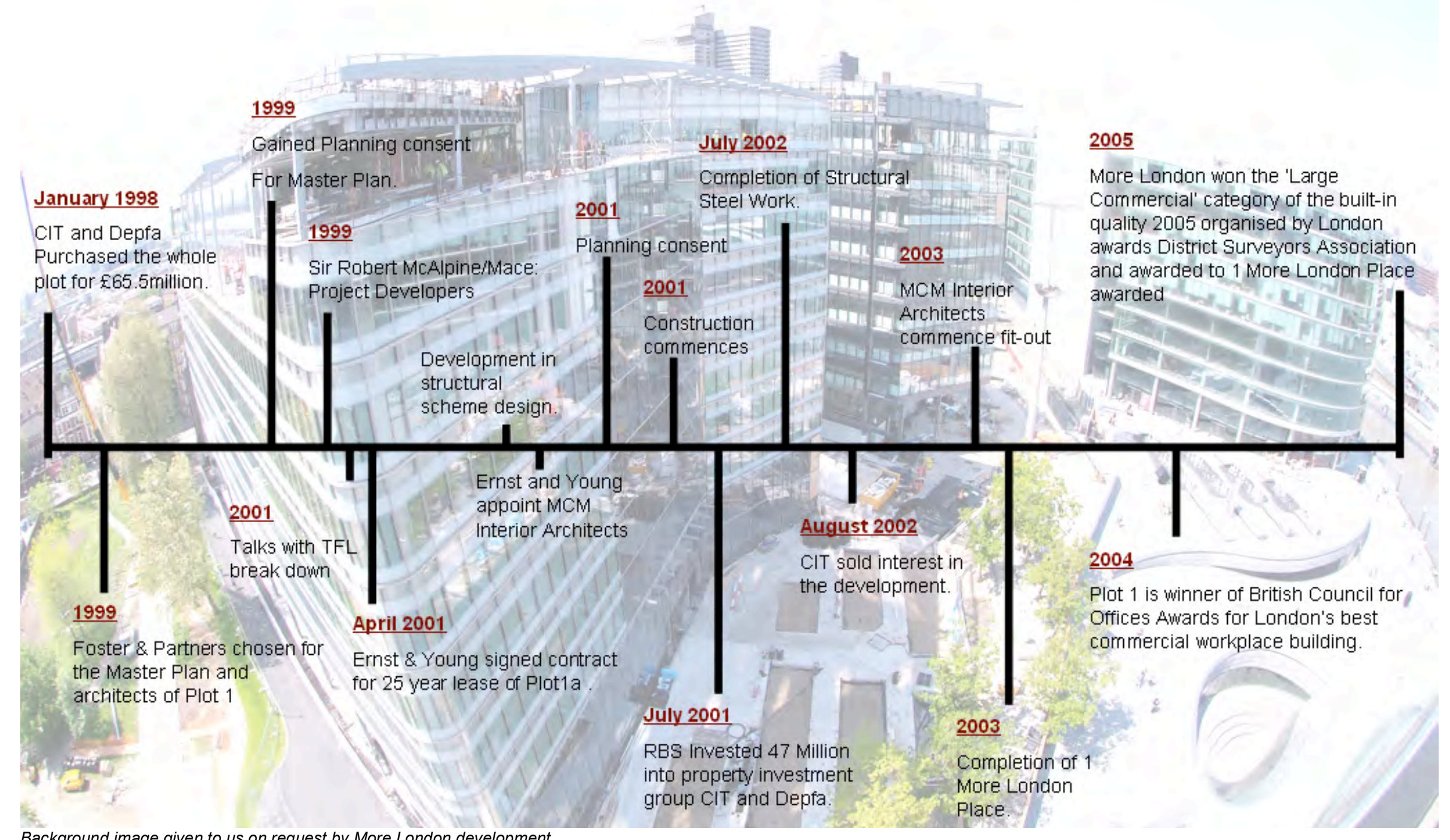

Background image given to us on request by More London development 
Double click here to type title of paper

The cash flow between the parties involved in the production of Plot 1 is essential to its production.

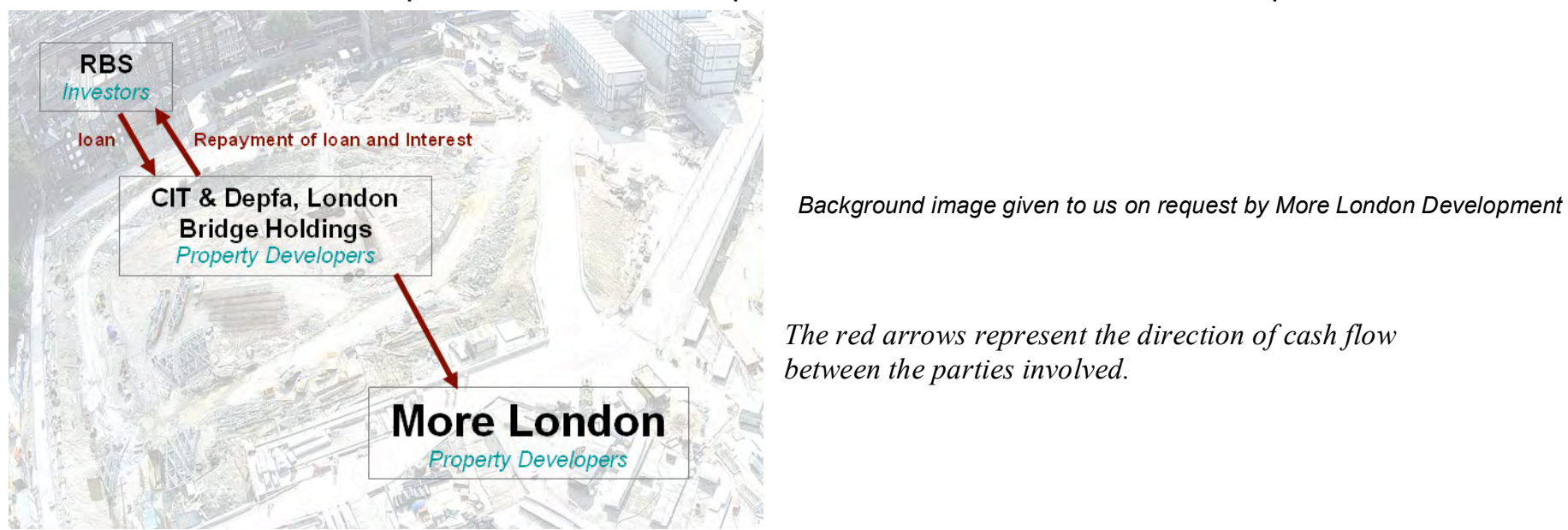


Figure 7: Arsenal Football Club. A highly complex set of projects, cross-subsidising and legitimising each other; highly controversial and involving a large number of architects, developers and users. This is an overview drawing. Students Giulia Cerundolo, Hugh Scott Moncrieff, Efemina Nakpodia, Zheng Wang

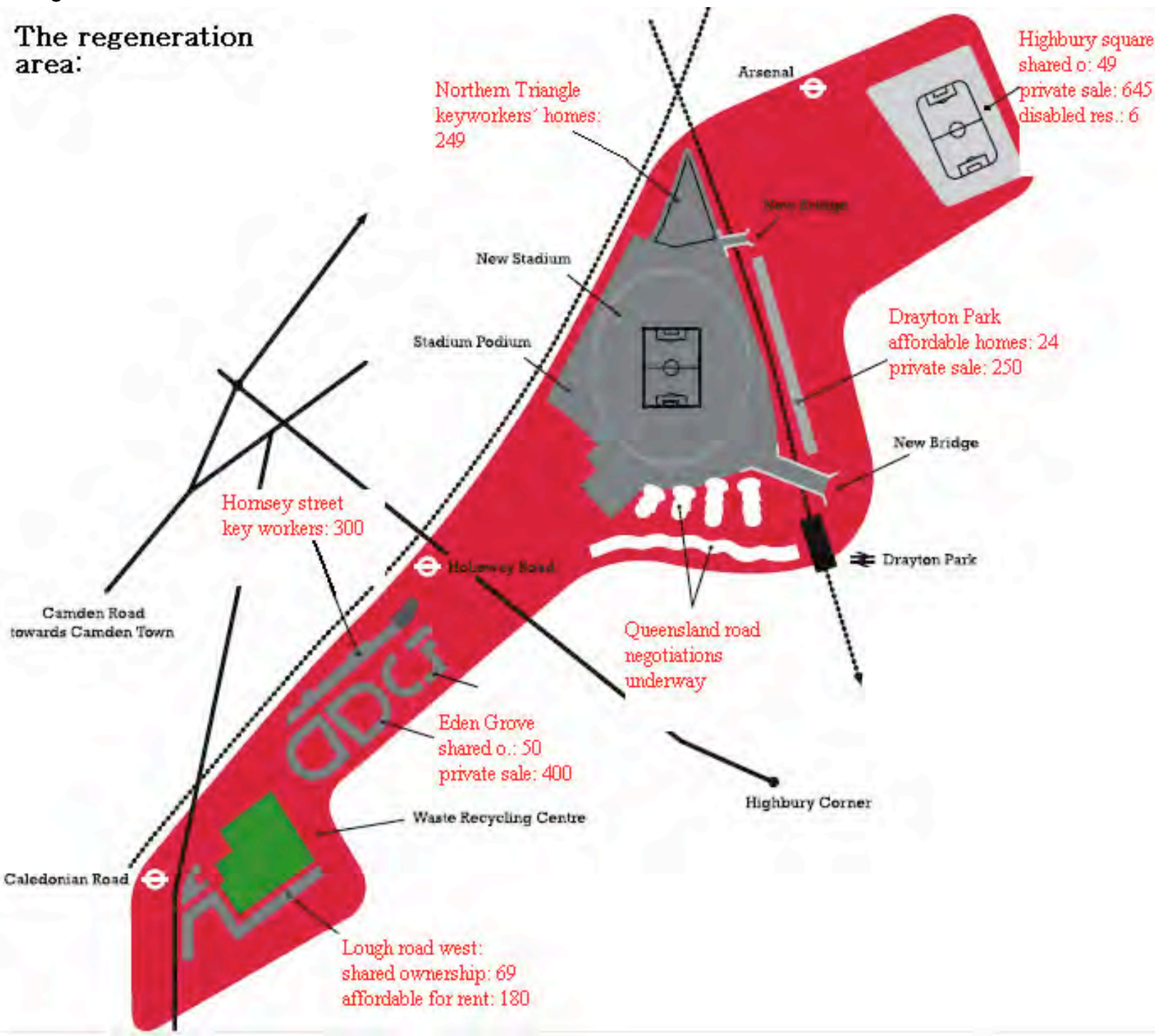


Figure 8 The Imagination Building in Bloomsbury (project by Mia Day, Natalia Eddy, Nick Dufeu, Harry Tweddell, Tess Martin)

Changes through time

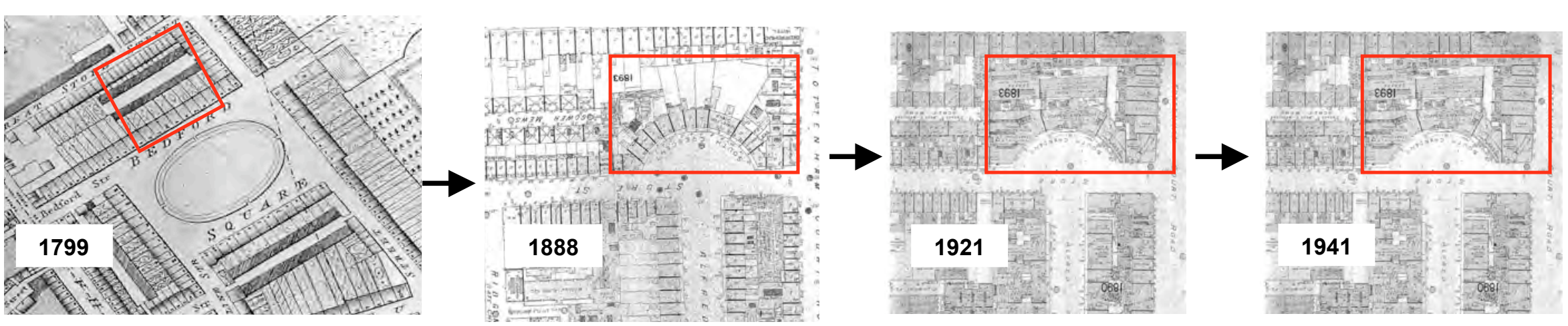

${ }^{i}$ A concern with the identity of the architect, the history of the notion of the architect and architectural professionalism, is a research and teaching and research interest that links the work of different faculty members across the Bartlett. For example, see Jonathan Hill's The Illegal Architect (1998) and Jane Rendell's (Un)doing it yourself: rhetorics of architectural abuse (1998); lain Borden's Manual: the Architecture and Office of Allford Hall Monaghan Morris (2003); and the Masters in Architectural History module The Foundation of the Architect, coordinated by Professor Adrian Forty. In some respects the course realises theoretical and pedagogic concerns of the Bartlett International Summer Schools on the Production of the Built Environment (BISS) which operated from 1969 to 1996, producing annual volumes of Proceedings.

We are grateful to one anonymous referee who responded on the baisis of a very close and sympathetic reading; we wish we had been able to respond sdequately to all those comments. 